\title{
АВТОМАТИЗОВАНА СИСТЕМА СТЕЖЕННЯ ЗА ЗІНИЦЯМИ ОЧЕЙ
}

Соломін A.B., доцент andr-sol@i.ua

Корнієнко Г.А. асистент galinakor5555@gmail.com

Коваленко М.В., студент maxeladze@gmail.com Факультет біомедичної інженерії Національний технічний університет України «Київський політехнічний інститут імені Ігоря Сікорського» м. Київ, Україна

Реферат - Проблема спілкування з оточенням паралізованих пацієнтів, які втратили мову, залишається актуальною в наш час, хоча з'явилися потужні технічні засоби і навіть використовуються небезпечні інвазивні технології. Будь-які додаткові можливості створення каналів спілкування покращать життя таких пацієнтів, а отже мають практичне значення.

B статті запропоновано технологію, алгоритм і реалізачію в програмному середовищі NI LabVIEW автоматизованоі системи стеження за зіничями очей, щьо може служити головною складовою частиною такого каналу спілкування. Завдяки подібній системі можна побудувати засоби визначення напряму погляду людини і фіксації «натискання» поглядом клавішей віртуальної клавіатури. Реалізація в програмному середовищі NI LabVIEW забезпечує легке підключення до апаратури, універсальність та простоту подальшої модифікаиії алгоритмів роботи.

Ключові слова - втрата мови, аналіз зображень, розпізнавання примітивів, машинний зір, керування «поглядом», алгоритм Хафа, виділення контурів, бінаризачія, NI LabVIEW

\section{І. ВСТУП}

Будь-які технології, що здатні сприяти можливості спілкування 3 оточенням, надзвичайно важливі для паралізованих пацієнтів, які втратили мову. Для цього використовують навіть небезпечні інвазивні методики. Один з варіантів створення каналу такого спілкування для деяких станів паралічу може бути реалізовано шляхом розробки наступного програмно-апаратного комплексу.

Спрямована на обличчя пацієнта відеокамера фіксує i передає послідовні зображення на вхід спеціальної комп'ютерної програми, яка в автоматичному режимі виділяє зображення зіниць очей, обчислюючи положення їх центрів.

Далі, наприклад, на екрані проектора відображується віртуальна клавіатура. Пацієнт фіксує послідовно погляд на клавішах клавіатури, а комп'ютерна система, стежачи за рухами зіниць очей, складає відповідні літери у слова і речення, доступні оточенню.
Іншим варіантом використання подібної системи може бути «натискання» поглядом клавіш керування роботизованих комплексів паралізованими пацієнтами або операторами, руки яких зайняті іншими елементами керування, наприклад пілотами в деяких ситуаціях.

\section{II. МЕТА ДОСЛІДЖЕННЯ}

Мета роботи: розробка програмного забезпечення для автоматизованої системи стеження за зіницями очей, що сприятиме створенню каналів спілкування для паралізованих пацієнтів та додаткових засобів керування «поглядом».

\section{III. МАТЕРІАЛИ І МЕТОДИ}

Для досягнення поставленої мети була побудована відповідна комп’ютерна програмна система (рис.1).

Для селекції зіниць на зображенні обличчя використано алгоритм пошуку примітивів, заснований на перетвореннях 
Хaфа (Hough), та його реалізація в програмному середовищі NI LabVIEW $[1,2]$.

Головна ідея алгоритму Хафа полягає в наступному. Реалізується перетворення координат точок простору зображення у простір параметрів шуканих примітивів (в даному випадку - кіл з різними радіусами і положеннями центра). Всі кола описуються рівняннями

$$
\left(\mathrm{x}-\mathrm{x}_{0}\right)^{2}+\left(\mathrm{y}-\mathrm{y}_{0}\right)^{2}=\mathrm{R}^{2}
$$

де $\mathrm{x}_{0}$, $\mathrm{y}_{0}$ та $\mathrm{R}$ - параметри, які відповідають різним колам. Якщо побудувати перетворення всіх точок (x, у) простору зображення в простір параметрів i рахувати рівень «голосування» (кількість вкладів) кожної точки вхідного простору при перетворенні в точку простору параметрів, то будуть утворюватись локальні максимуми, які відповідають колам зображення вхідного простору, оскільки кожна точка (х, у) може належати безлічі можливих кіл 3 різними параметрами, але якщо якась множина точок дійсно утворює коло, то для результуючої точки 3 параметрами такого кола буде спостерігатись максимум. Введена таким чином функція підрахунку відгуків («голосів») називається акумуляторною функцією.

Таким чином селекція кіл вхідного простору зводиться до виявлення локальних максимумів акумуляторної функції у просторі параметрів.

Блок-діаграма розробленого віртуального приладу для виділення зіниць людини на зображенні за алгоритмом перетворень Хафа в програмному середовищі NI LabVIEW наведена на рис. 1.
Послідовність обробки вхідного зображення наступна. Після відображення на графічному дисплеї Image Original реалізується виділення контурів віртуальним підприладом IMAQ EdgeDetection. Для цього використовується алгоритм Прюітт (Prewitt), ідея якого полягає в знаходженні локальної орієнтації ділянки контуру в околиці кожного пікселя обчисленням максимального відгуку на множині ядер згортки, кожне 3 яких відповідає оператору похідної вздовж конкретного напрямку $[1,2,3]$.

Далі відбувається інверсія зображення контурів віртуальним приладом IMAQ Inverse i відображення результатів на графічному дисплеї Image modified 3.

Після цього зображення піддається бінаризації за допомогою віртуального підприладу IMAQ AutoBThreshold 2, який в напівавтоматичному режимі на основі статистичного аналізу підбирає оптимальне значення порогу бінаризації та виконує цю бінаризацію, тобто перетворює напівтонове зображення в бінарне. Результат відображується на графічному дисплеї Image modified 2.

Далі віртуальним підприладом IMAQ Find Circles реалізується описаний вище алгоритм Хафа пошуку кіл серед множини точок бінарного зображення. Результат відображується на графічному дисплеї Image modified у вигляді двох білих кілець, що відповідають зіницям очей, а також для контролю відображується накладанням на оригінальне зображення обличчя на графічному дисплеї Image Original у вигляді двох червоних кілець. Для такого накладання

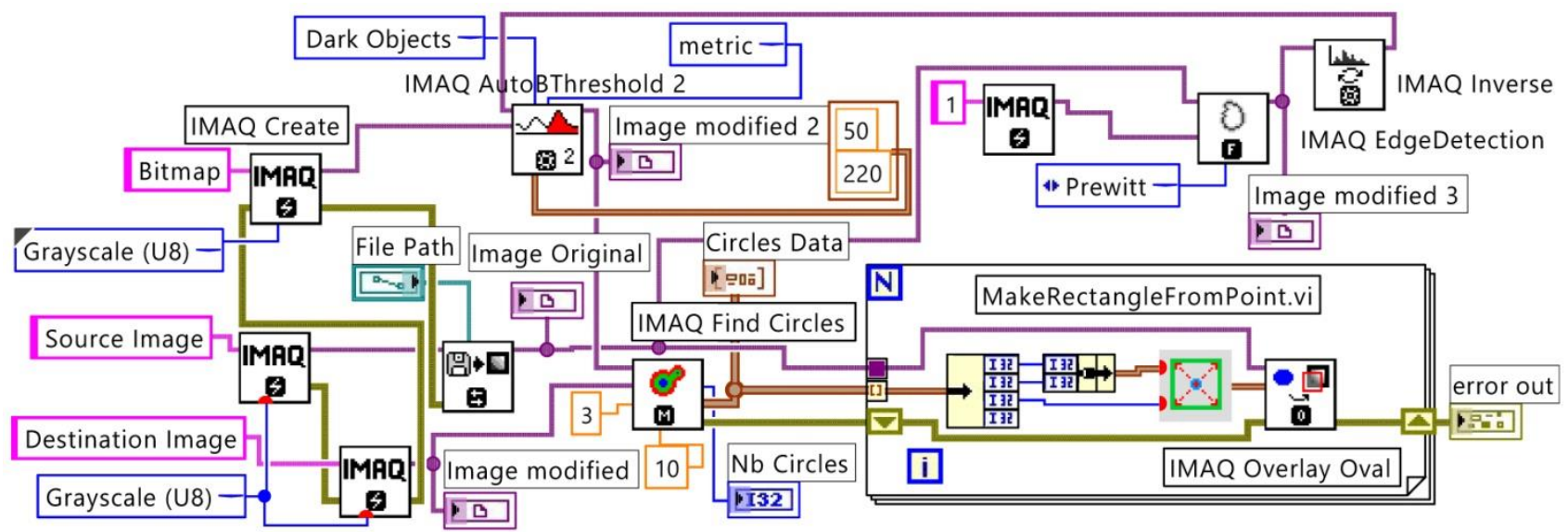

Рис. 1. Блок-діаграма віртуального приладу для виділення зіниџь людини на зображенні за алгоритмом перетворень Хафа 
служить частина блок-діаграми (рис. 1), що розміщена в циклі праворуч та включає віртуальні підприлади IMAQ Overlay Oval та MakeRectangleFromPoint.vi.

Сукупність модулів IMAQ Create призначена для створення програмних змінних (фрагментів пам'яті комп'ютера) 3 різними назвами, означеними відповідними константами, для зберігання зображень на кожному етапі їх обробки $[1,2]$.

Але вищезазначені результати на екранах мають лише ілюстративний сенс. Головне, що має використовуватись в подальшому - це масив 3 двох пар координат центрів зіниць Circles Data. Саме на основі цих значень працюватиме система фіксації погляду пацієнта.

Сукупність графічних дисплеїв із згаданими вище результатами наведена на рис. 2.
У модулі IMAQ Find Circles можна задати діапазон можливих значень радіусів шуканих кіл (на рис.1 це діапазон 3 - 10).

Крім того, наприклад, у модулі бінаризації передбачено кілька варіантів алгоритмів статистичного аналізу для автоматичного визначення оптимального порогу бінаризації: clustering, entropy, metric, moments, inter-class variance.

У модулі виділення контурів IMAQ EdgeDetection також можливе використання декількох алгоритмів: Differentiation, Gradient, Prewitt, Roberts, Sigma, Sobel.

Програмним середовищем розробки системи обрано NI LabVIEW саме через універсальність, зручність та різноманіття бібліотек модулів, особливо для обробки зображень, а також надзвичайно просте підключення апаратних засобів $[4,5,6]$.

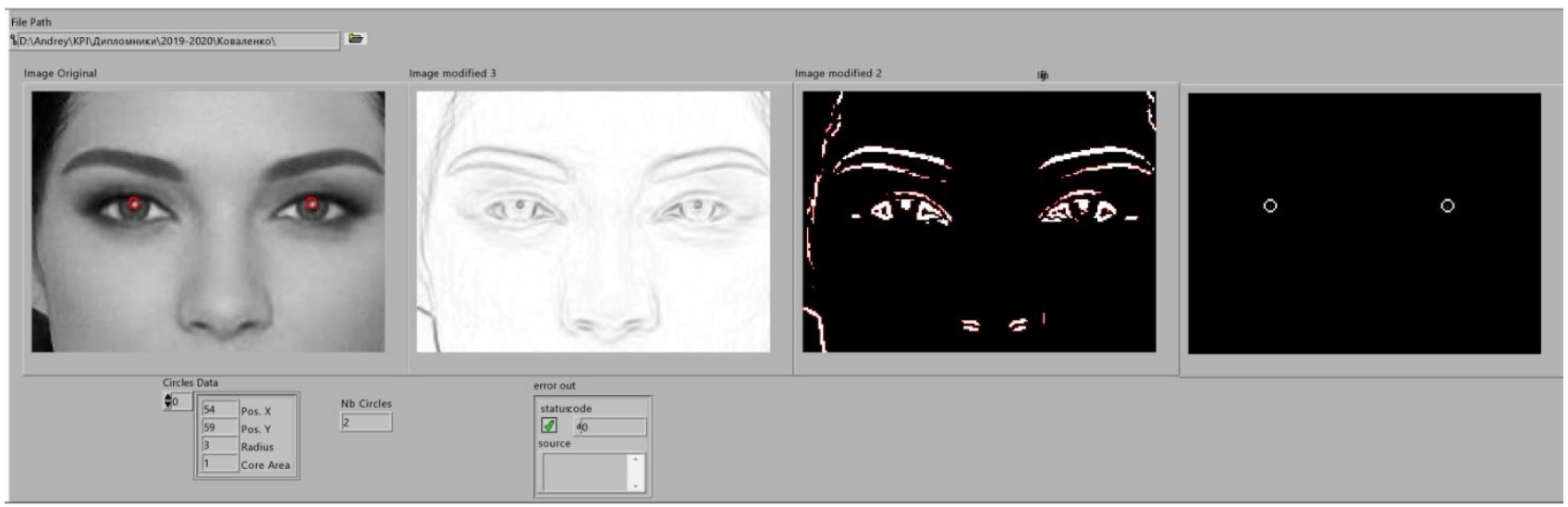

Рис. 2. Сукупність графічних дисплеїв з результатами послідовної обробки зображення з метою виділення зіниць

\section{IV. РЕЗУЛЬТАТИ ТА ОБГОВОРЕННЯ}

Більшість модулів системи в автоматичному режимі налаштовуються на оптимальний режим, наприклад, як раніше згадувалось, в модулі IMAQ AutoBThreshold 2 поріг бінаризації визначається автоматично на основі статистичного аналізу гістограми розподілу яскравостей пікселів зображення.

В той же час існують можливості додаткових налаштувань параметрів і навіть типів алгоритмів обробки інформації окремих модулів для випадків спеціальних умов застосувань. Так, у модулі бінаризації IMAQ AutoBThreshold 2 можна в ручному режимі задати межі можливих значень порогу (на рис.1 вони мають значення $50-220$ ).

\section{V. ВИСНОВКИ}

1. Використання програмного середовища NI LabVIEW $€$ перспективним напрямом побудови систем обробки і аналізу відеоінформації. Однією 3 важливих переваг $є$ можливість здійснювати модифікації алгоритмів навіть не фахівцями-програмістами.

2. Розроблена система стеження за зіницями може застосовуватись для створення каналів спілкування 3 паралізованими пацієнтами та засобів керування «поглядом» в складних умовах взаємодії з апаратурою.

3. Аналогічні принципи i алгоритми перспективно використовувати при побудові систем машинного зору в роботизованих комплексах [7]. 


\section{ПЕРЕЛІК ПОСИЛАНЬ}

[1] Визильтер Ю. В. Обработка и анализ цифровых изображений с примерами на LabVIEW / Ю.В.Визильтер, С.Ю. Желтов, В.А.Князь, А.Н.Ходарев, А.В.Моржин. М.: ДМК Пресс, 2007. - 464 с.

[2] Klinger T. Image processing with LabVIEW and IMAQ Vision. - Prentice Hall, 2003. - 319 p.

[3] Samuel J. Dwyer III. A personalized view of the history of PACS in the USA. In: Proceedings of the SPIE, «Medical Imaging 2000: PACS Design and Evaluation: Engineering and Clinical Issues», edited by G. James Blaine and Eliot L. Siegel. 2000;3980:2-9
[4] Програмування в NI LabVIEW. Технологія розробки віртуальних приладів : навч. посіб. / О.Г. Кисельова, А.В. Соломін. - К. : НТУУ «КПІ», 2014. - 276 с.

[5] Суранов А. Я. LabVIEW 7: Справочник по функциям. М.: ДМК Пресс, 2005. - 512 c.

[6] Бутырин П. А. и др. Автоматизация физических исследований и эксперимента: компьтерные измерения и виртуальные приборы на основе LabVIEW 7 / Под ред. Бутырина П. А. - М.: ДМК Пресс, 2005. - 264 с.

[7] Гонсалес Р., Вудс Р., Цифровая обработка изображений. M.: Техносфера, 2005. - 1072 c.

\title{
УДК 004.93
}

\section{АВТОМАТИЗИРОВАННАЯ СИСТЕМА СЛЕЖЕНИЯ ЗА ЗРАЧКАМИ ГЛАЗ}

\author{
Соломин A.B., доцент \\ andr-sol@i.ua \\ Корниенко Г.А. ассистент \\ galinakor5555@gmail.com \\ Коваленко М.В., студент \\ maxeladze@gmail.com \\ Факультет биомедицинской инженерии \\ Национальный технический университет Украины \\ «Киевский политехнический институт имени Игоря Сикорского» \\ г. Киев, Украина
}

\begin{abstract}
Реферат - Проблема общения с окружающими парализованных пачиентов, потерявших речь, остается актуальной в наше время, хотя появились мощные технические средства и даже используются опасные инвазивные технологии. Любые дополнительные возможности создания каналов общения улучшат жизнь таких пациентов, и поэтому имеют практическое значение.

В статье предложена технология, алгоритм и реализащия в программной среде NI LabVIEW автоматизированной системы слежения за зрачками глаз, которая может служить основой такого канала общения. Благодаря подобной системе можно построить средства определения направления взгляда человека и фиксации «нажатия» взглядом клавишей виртуальной клавиатуры. Реализачия в программной среде NI LabVIEW обеспечивает легкое подключение к аппаратуре, универсальность и простоту дальнейшей модификации алгоритмов работы.
\end{abstract}

Ключевые слова - потеря речи, анализ изображений, распознавание примитивов, машинное зрение, управление «взглядом», алгоритм Хафа, выделения контуров, бинаризация, NI LabVIEW 


\title{
UDC 004.93
}

\section{AUTOMATED EYE OPERATION MONITORING SYSTEM}

Solomin A., assistant professor andr-sol@i.ua

Kornienko G., assistant galinakor5555@gmail.com

Kovalenko M., student maxeladze@gmail.com

Faculty of Biomedical Engineering National Technical University of Ukraine "Igor Sikorsky Kyiv Polytechnic Institute"

Kyiv, Ukraine

\begin{abstract}
The problem of communicating with surrounding by paralyzed patients who have lost their speech remains relevant in our time, although powerful technical means have appeared and even dangerous invasive technologies have been used. Any additional opportunities for creating communication channels will improve the lives of such patients, and therefore are of practical importance.

The article proposes a technology, algorithm and implementation in the NI LabVIEW software environment of an automated system for tracking eye pupils, which can serve as the basis for such a communication channel. Thanks to such a system, it is possible to build means for determining the direction of a person's gaze and fixing the "pressing" with a gaze using the virtual keyboard key. Implementation in the NI LabVIEW software environment provides easy connection to the equipment, versatility and simplicity of further modification of the operation algorithms.
\end{abstract}

Keywords - speech loss, image analysis, recognition of primitives, machine vision, "gaze" control, Hough algorithm, contouring, binarization, NI LabVIEW 